\title{
In Vitro Diagnosis of Immediate Drug Hypersensitivity Anno 2017: Potentials and Limitations
}

\author{
I. I. Decuyper ${ }^{1,2} \cdot$ E. A. Mangodt ${ }^{1}$ A. L. Van Gasse ${ }^{1,2} \cdot$ K. Claesen ${ }^{1} \cdot$

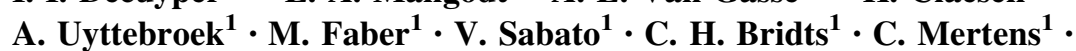 \\ M. M. Hagendorens ${ }^{1,2} \cdot$ L. S. De Clerck ${ }^{1} \cdot$ Didier G. Ebo $^{1}$
}

Published online: 4 March 2017

(c) The Author(s) 2017. This article is published with open access at Springerlink.com

\begin{abstract}
Background For most physicians, quantification of drugspecific immunoglobulin E (drug-sIgE) antibodies constitutes the primary in vitro measure to document immediate drug hypersensitivity reactions (IDHR). Unfortunately, this is often insufficient to correctly identify patients with IgEmediated IDHR and impossible for non-IgE-mediated IDHR that result from alternative routes of basophil and mast cell activation. In these difficult cases, diagnosis might benefit from cellular tests such as basophil activation tests (BAT).

Aim The aim was to review the potential and limitations of quantification of SIgE and BAT in diagnosing IDHR. The utility of quantification of serum tryptase is discussed.

Methods A literature search was conducted using the key words allergy, basophil activation, CD63, CD203c, diagnosis, drugs, hypersensitivity, flow cytometry, specific $\operatorname{IgE}$ antibodies; this was complemented by the authors' own experience.

Results The drugs that have been most studied with both techniques are $\beta$-lactam antibiotics and curarizing neuromuscular blocking agents (NMBA). For sIgE morphine,
\end{abstract}

Didier G. Ebo

immuno@uantwerpen.be

1 Laboratory of Immunology, Department of Immunology, Allergology, Rheumatology, Faculty of Medicine and Health Science, Antwerp University Hospital, University of Antwerp, CDE T5.95, Universiteitsplein 1, 2610 Antwerp, Belgium

2 Department of Paediatrics, Faculty of Medicine and Health Science, Antwerp University Hospital, University of Antwerp, Antwerp, Belgium data are available on the value of this test as a biomarker for sensitization to substituted ammonium structures that constitute the major epitope of NMBA, especially rocuronium and suxamethonium. For the BAT, there are also data on non-steroidal anti-inflammatory drugs (NSAIDs) and iodinated radiocontrast media. For $\beta$-lactam antibiotics, sensitivity and specificity of $\operatorname{sIgE}$ varies between 0 and $85 \%$ and 52 and $100 \%$, respectively. For NMBA, sensitivity and specificity varies between 38.5 and $92 \%$ and 85.7 and $100 \%$, respectively. Specific IgE to morphine should not be used in isolation to diagnose IDHR to NMBA nor opiates. For the BAT, sensitivity generally varies between 50 and $60 \%$, whereas specificity attains $80 \%$, except for quinolones and NSAIDs.

Conclusions Although drug-sIgE assays and BAT can provide useful information in the diagnosis of IDHR, their predictive value is not absolute. Large-scale collaborative studies are mandatory to harmonize and optimize test protocols and to establish drug-specific decision thresholds.

\section{Key Points}

Although drug provocation tests are considered the gold standard for immediate drug hypersensitivity reactions, their entrance in mainstream application is severely hampered for obvious ethical reasons.

Although drug-specific immunoglobulin E antibody assays and basophil activation tests can add to the diagnosis of immediate drug hypersensitivity reactions, their predictive value for a future clinical outcome is not absolute. 


\section{Introduction}

The gold standard for correct diagnosis of immediate drug hypersensitivity reactions (IDHR) are controlled drug provocation tests (DPT) with the culprit compound(s). However, DPT entail a considerable risk of severe, lifethreatening complications and can simply be contraindicated (i.e. in patients having already suffered from lifethreatening reactions and patients taking $\beta$-blockers or angiotensin-converting enzyme inhibitors) or impossible for obvious reasons [i.e. hypersensitivity to curarizing neuromuscular blocking agents (NMBA)]. Moreover, DPT do not show absolute predictive values and might yield false negative results [1]. Consequently, diagnostic DPT are still mainly confined to research settings. As a result, a diagnostic workup for IDHR comprises a thorough history complemented with skin tests and/or in vitro quantification of (commercially available) specific immunoglobulin E (sIgE) antibodies when an IgE-mediated mechanism with activation of mast cells and basophils is suspected. Unfortunately, only a few drug-specific IgE (drug-sIgE) assays are available, and most of them have not been thoroughly validated. Furthermore, IDHR might not per se involve IgE/high-affinity IgE receptor (FceRI)-cross-linking, but may also result from alternative pathways, such as a ligation of the Mas-related G-protein receptor MRGPRX2 [2, 3], that cannot be detected by an $\operatorname{sigE}$ antibody assay. The development and validation of cellular tests such as basophil activation tests (BAT) might, somewhat, hold promise in such cases. Starting from our clinical priorities and expertise, the objective of this manuscript is to review the literature on the value of serum tryptase, commercially available drug-sIgE assays and BAT in the diagnosis of IDHR. Emphasis is put on some particular misconceptions, shortcomings, and unmet needs. As with any subject still beset by many questions, alternative interpretations, hypotheses, or explanations expressed here may not find universal acceptance.

\section{Principles of Quantification of Drug-Specific Immunoglobulin E Antibodies and Basophil Activation Tests}

IgE antibodies were discovered in 1967 as the 'reagines' responsible for so-called type I hypersensitivity reactions $[4,5]$. Five years later, the first in vitro assay for serum sIgE antibodies, the so-called radio allergosorbent test (RAST), was developed and commercialized. The original RAST was designed as a cyanogen-bromide activated paper disc, on which native allergen extracts were covalently coupled and sIgE antibodies that bind with the allergen were quantified with radio-iodinated polyclonal antihuman IgE antibodies using a $\gamma$-counter [6]. At present, quantification of drug-sIgE antibodies predominantly relies upon quantification of a drug-(hapten)-carrier antibody complex in which the secondary antihuman IgE is conjugated to an enzyme with colorimetric reading in the enzyme-linked immunosorbent test (ELISA) or with a fluorescence reading in the fluorescent enzyme immunoassay (FEIA) [7]. However, unlike protein allergens, only a limited number of drug-specific immunoassays are available. The only drug-sIgE assays that are currently commercially available from Thermo Fisher are penicilloyl $\mathrm{G}$, penicilloyl $\mathrm{V}$, ampicilloyl and amoxicilloyl determinants, cephaclor, the antiseptic chlorhexidine, chymopapain, bovine gelatin, human, bovine and porcine insulin, morphine (marker for sensitization to tertiary and quaternary substituted ammonium determinants), pholcodine and suxamethonium. For research purposes only, additional assays such as adrenocorticotropic hormone, atracurium, bacitracin, carboplatin, cefamandole, cefoxitin, cefotaxime, cefuroxime, cisplatinum, mepivacaine, methylprednisolone-21-succinate, nafamostat (4-guanidinobenzoic acid), oxaliplatin, penicillin minor determinants (e.g. penicillanyl), propyphenazone, protamine, rocuronium, and tetanus toxoid are offered via the Thermo Fisher Scientific special allergen service. However, most of these assays have not been thoroughly validated, mainly as a result of the unavailability of sufficient numbers of accurately phenotyped patients and exposed or challenged control individuals.

Basophils represent less than $1 \%$ of the peripheral blood leukocytes. Basophils develop from CD34+ pluripotent progenitor stem cells, exhibit a segmented nucleus and are identifiable by metachromatic staining with basic dyes (e.g. toluidine blue). Like tissue resident mast cells, basophils can be triggered by IgE-dependent and various IgE-independent ways. Cross-linking of the surface-bound FceRI generally occurs through (glyco)proteins, chemical allergens or auto-antibodies directed against the FceRI receptor or membrane-bound $\mathrm{IgE}$ antibodies. If not IgE-dependent, activation will mainly result from coupling of receptors with endogenous (e.g. cytokines, anaphylatoxins, chemokines, IgG, neuropeptides) or exogenous (e.g. pathogen-associated molecular patterns) elements. Recently, McNeil et al. [2] described the potential of MRGPRX2-related mast cell activation by various drugs containing a tetrahydroisoquinoline (THIQ) motif, such as some quinolones and NMBA. Alternatively, other largely unknown pathways (e.g. direct mast cell degranulation by opiates, iodinated contrast media and vancomycin) might also induce degranulation of basophils and mast cells. Upon activation, basophils and mast cells will release a myriad of mediators that are responsible for the early and 
late phase manifestations of the immediate allergic reaction.

The foundations of current flow-assisted BAT were laid 25 years ago [8], and in the meantime, the technique has largely supplanted older mediator release assays that rely upon difficult quantification of mediators released in the supernatant. The technical principles and requirements of BAT have been detailed elsewhere [9]. Traditional BAT relies upon a flow cytometric analysis of various activation and degranulation markers on the surface membrane. These changes can be detected and quantified on a single-cell level using specific monoclonal antibodies conjugated with different LASER-excitable fluorochromes. For example, basophils are traditionally identified by markers such as CCR3 (CD193)/CD3, CD123/HLA-DR or IgE/CD203c. Of these markers, only CD203c, the ectonucleotide pyrophosphatase/phosphodiesterase family member 3 enzyme (E-NPP3), is lineage specific. After activation, the appearance or up-regulation of surface activation and/or degranulation markers, such as CD63 and/or CD203c, is quantified [9-14]. Although there is controversy about CD63 being the optimal readout for basophil activation [15], it is of note that for the time being, only the appearance of CD63 seems to reflect anaphylactic degranulation with significant release of histamine [16] (see also Fig. 1).

Alternative methods to measure basophil activation imply quantification of surface inhibitory receptor CD300a expression [17] and phosphorylation of signalling molecules such as p38 mitogen-activated protein kinase (MAPK) [18] and signal transducer and activator of transcription (STAT) 5 [19]. In addition, it was demonstrated that histamine release can also be quantified by flow cytometry. In this technique, designated as HistaFlow, the intracellular content of histamine and its release are analysed by an enzyme affinity method using the histaminase diamine oxidase [20]. Figures 1 and 2 show a representative HistaFlow dotplot of a cefazolin- and pholcodine-reactive patient, respectively. Note the specificity of the test, as basophils of the pholcodine allergic patient do not respond to structurally similar opiates, i.e. morphine and codeine, that are tolerated by the patient.

\section{3 及-Lactam Antibiotics}

The most studied sIgE assays are those for $\beta$-lactam antibiotics, especially amoxicillin and benzyl penicilloyl. Although, several cases of positive sIgE results in IDHR with negative skin tests have been described [21-25], sIgE assays for $\beta$-lactams generally show a low sensitivity that decreases over time [26], as is shown in Table 1. In contrast, specificity generally appears to be high, but in some studies, disappointing specificity data have been observed [22, 24, 27-30]. In some studies, false positivity could have resulted from nonspecific binding in the solid phase assay as a result of elevated total IgE titres [28-31]. However, Johansson et al. [31] found that $26 \%$ of the patients with a positive sIgE for penicillin have clinically irrelevant sIgE antibodies to phenylethylamine (PEA) and that these antiPEA antibodies test negative in a basophil activation assay. In summary, sIgE antibodies to $\beta$-lactams seem of limited value and should not be used in isolation to diagnose IDHR to these antibiotics. In order to avoid misdiagnosis, these assays should be complemented with BAT, skin testing and, where appropriate, a DPT [32, 33]. Table 2 summarizes the data of BAT in IDHR to $\beta$-lactams. Hitherto, ten studies have investigated the BAT as a diagnostic in IDHR to $\beta$-lactam antibiotics, mainly to amoxicillin. Compared with the quantification of sIgE antibodies, BAT shows a comparable sensitivity and specificity. As for sIgE, sensitivity of BAT to $\beta$-lactams is rather low and decreases over time [26].

\section{Quinolones}

IDHR to quinolones constitute a difficult pathomechanistic conundrum and pose a significant diagnostic challenge, mainly because of the absence of readily available quinolone sIgE assays and serious uncertainties associated with skin testing [34-36]. For example, we observed that moxifloxacin skin testing yielded a positive predictive value of $36 \%$ and negative predictive value of $25 \%$ [36].

Studies on the BAT with quinolones (Table 3) show that CD63-based assays frequently yield negative results [37-39], except for the study of Aranda et al. [40]. This might suggest that fluoroquinolones can trigger basophil activation which is difficult to depict by traditional CD63based assays. We speculate that the more consistent results with CD203c up-regulation [41, 42] might indicate mediator release in response to quinolones results from alternative degranulation pathways such as ligation of MRGPRX2 [2]. Moreover, such an IgE-independent activation mechanism might explain IDHR to quinolones upon first exposure in naïve patients and the frequent falsenegative sIgE results [40, 43].

\section{Neuromuscular Blocking Agents}

In many countries, curarizing NMBA represent a significant cause of anaesthesia-related anaphylaxis [44-48]. Skin tests are the primary instrument to confirm IDHR to NMBA [49]. However, the predictive value of skin testing is not absolute thereby leaving room for additional in vitro 

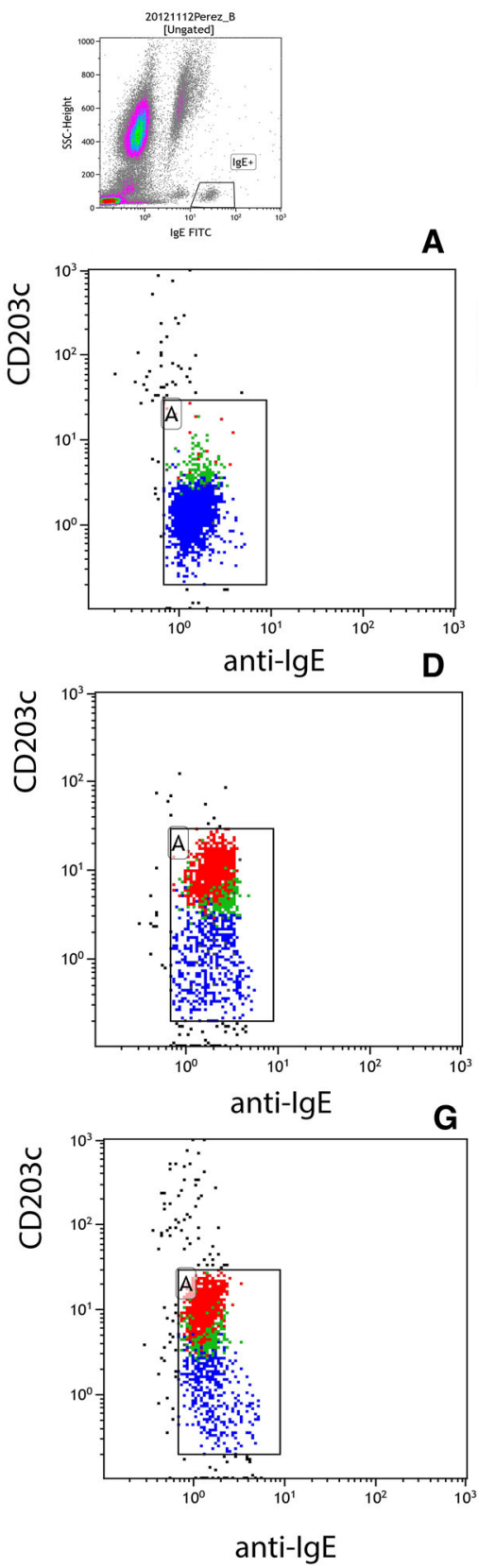

B
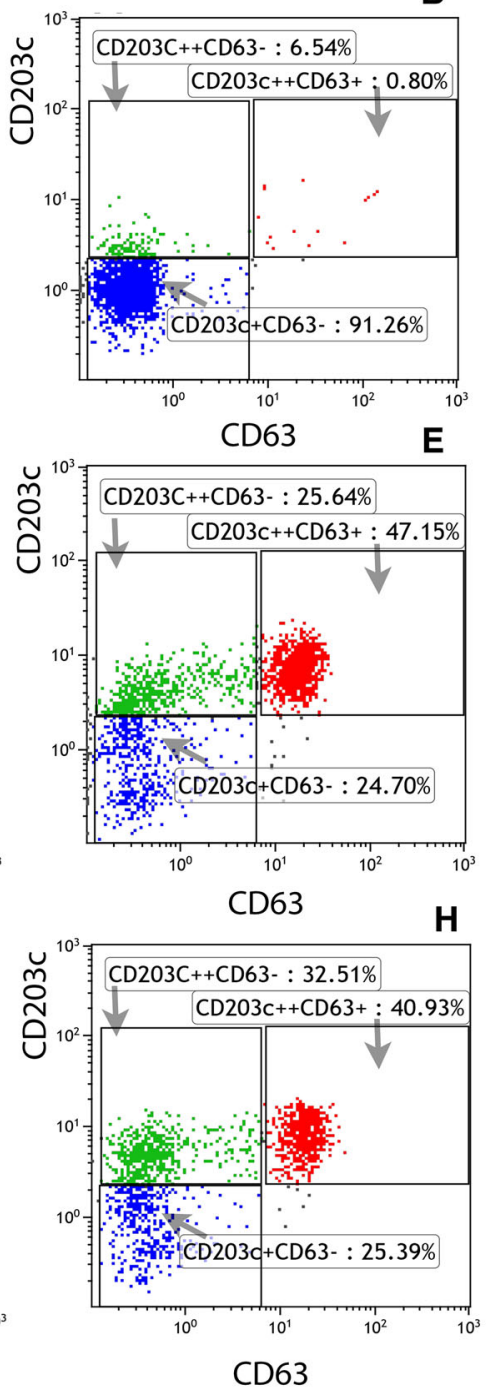
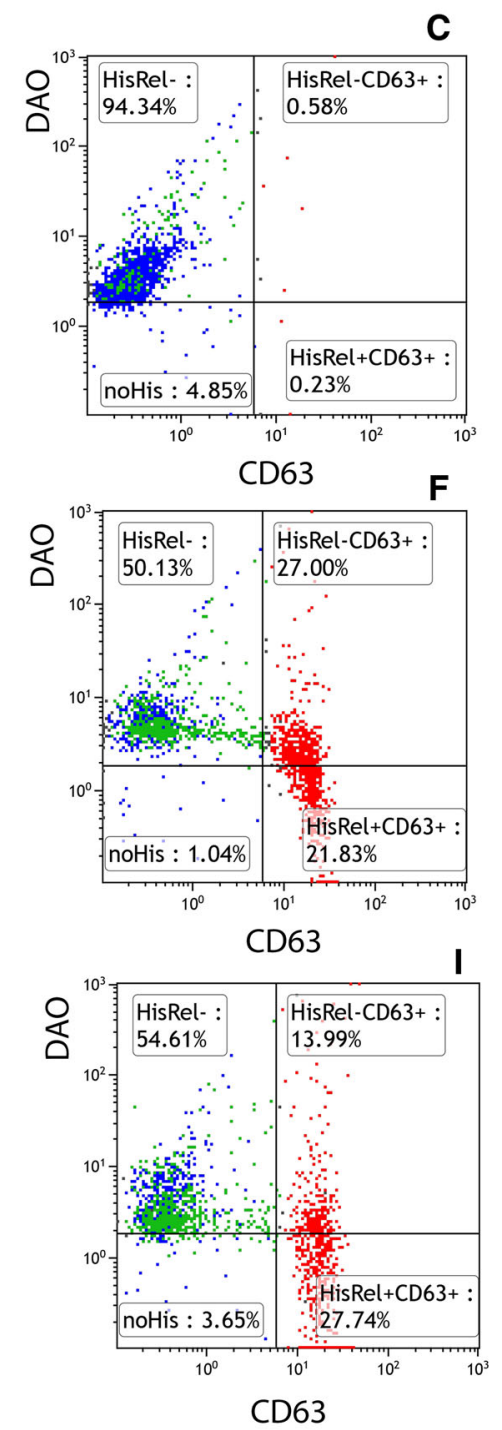

Fig. 1 HistaFlow plots in a cefazolin-reactive patient showing clear anaphylactic degranulation of basophils in response to cefazolin $(100 \mu \mathrm{g} / \mathrm{mL})$. a-c Resting cells stimulated with buffer; $\mathbf{d}-\mathbf{f}$ display the responses to positive control stimulation with anti-IgE; and $\mathbf{g}_{-}$

tests. In the absence of readily available assays, for about two decades, several groups have tried to define the accuracy of various home-made NMBA-sIgE assays (Table 4) [50-53]. At present, IDHR to NMBA are serologically assessed indirectly through assays measuring $\mathrm{IgE}$ reactivity to tertiary and quaternary substituted ammonium structures that have been shown to be the major epitopes of NMBA [54, 55]. Most frequently applied methods are a choline chloride $[50,51,56-61]$, a p-aminophenyl i THE response upon stimulation with the antibiotic. Note that only CD203c $++/$ CD63 + cells release histamine (decrease of DAO, $\mathbf{c}, \mathbf{f}$, i). See [110]. DAO diamine oxidase, HisRel histamine release, $I g E$ immunoglobulin $\mathrm{E}$

phosphoryl choline (PAPPC) $[50,56,57,62]$ and/or morphine-based assays [50-52, 62-67]. With respect to the ImmunoCAP FEIA for suxamethonium, rocuronium, atracurium and morphine, the sensitivity and specificity for the individual NMBA varies between 38.5 and $92 \%$ and 85.7 and $100 \%$, respectively. Furthermore, it has been demonstrated that a morphine-based immunoassay is a valuable test to detect suxamethonium- and rocuronium-reactive antibodies, but not to depict atracurium-reactive antibodies 

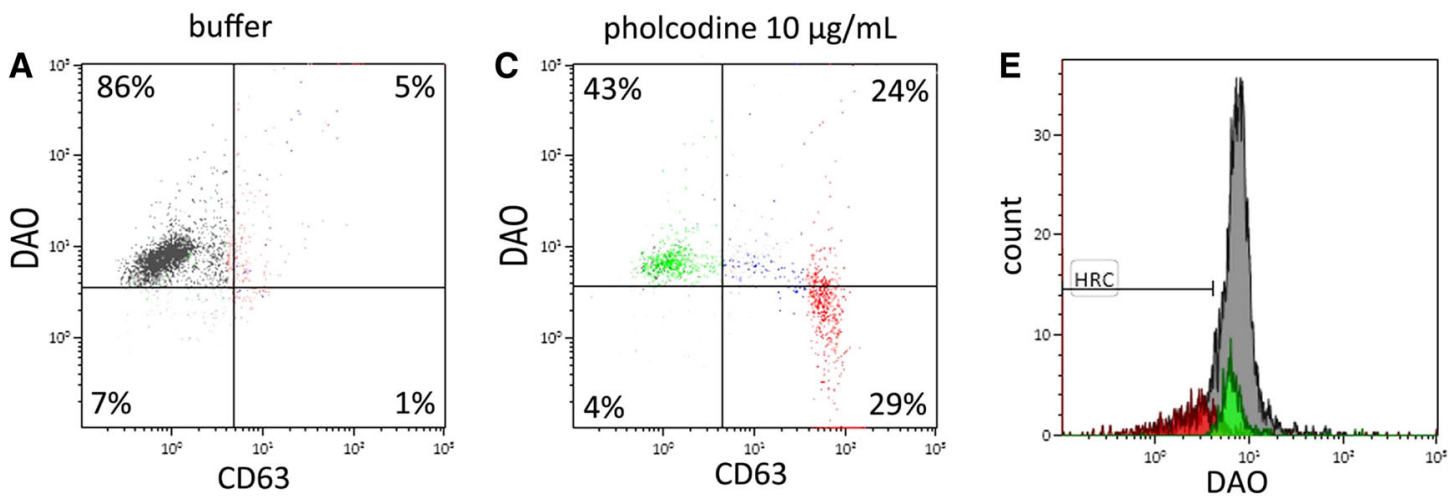

$\mathrm{HRC}=$ histamine releasing cells
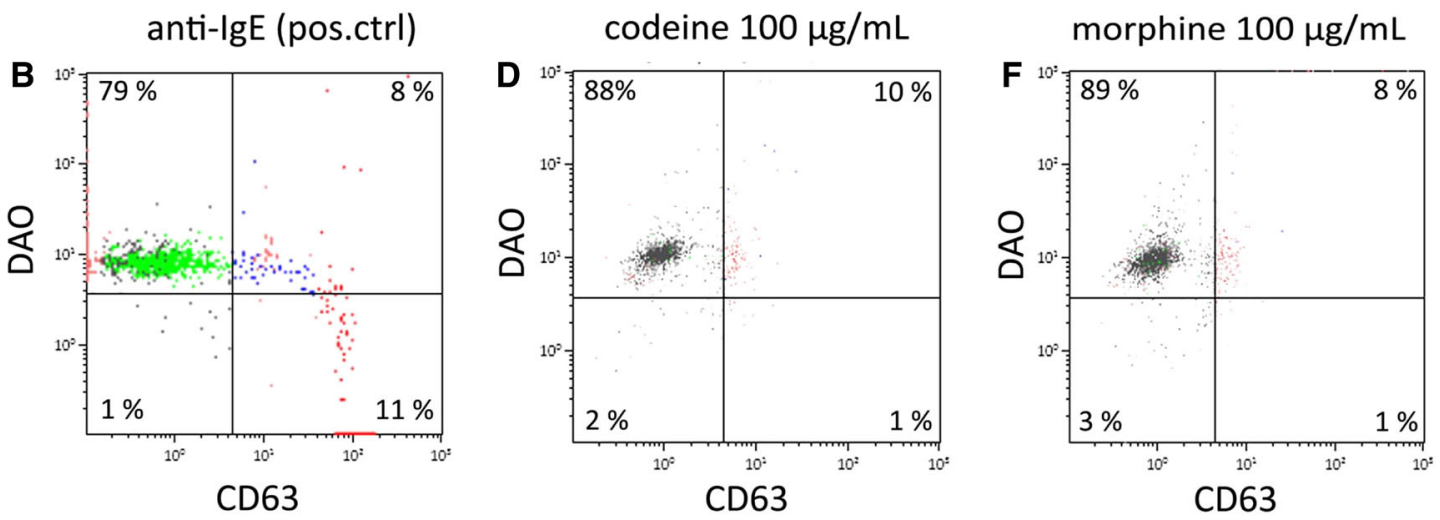

Fig. 2 Representative plot of CD63 appearance and histamine release in response to buffer, anti-IgE as a positive control, pholcodine $10 \mu \mathrm{g} / \mathrm{mL}$, and the structurally almost similar opiates codeine $(100 \mathrm{mg} / \mathrm{mL})$ and morphine $(100 \mu \mathrm{g} / \mathrm{mL})$ in a patient with

$[63,65]$. Quantifying IgE reactivity to tertiary and quaternary substituted ammonium structures to identify patients at risk or to document NMBA hypersensitivity [68, 69] might cause a large number of false-positive results as they are prevalent in the general population $[64,65,67]$; these assays can therefore not be used as a screening technique to identify patients at risk or to document NMBA hypersensitivity [68, 69]. The most important hypotheses for these false-positive sIgE results are an elevated total IgE [65] and intake of the opiate antitussive pholcodine [70]. Alternatively, as recently stressed by Spoerl et al. [3], IDHR to NMBA such as rocuronium might occur independently from IgE/FceRI cross-linking and relate to MRGPRX2-mediated activation of mast cells [2] and, therefore, not be depicted by sIgE assays.

Table 5 displays the data about BAT in IDHR to NMBA. In general, sensitivity of the assay varies between 36 and $92 \%$, whereas specificity easily reaches $95 \%$. Importantly, BAT not only enables identification of the culprit drug, but also provides the opportunity to study cross-reactivity and tailor safe alternatives for future anaesthesia [71, 72]. pholcodine allergy and a negative challenge for codeine and morphine [82]. DAO diamine oxidase, $I g E$ immunoglobulin E, pos.ctrl positive control

\section{Non-Steroidal Anti-inflammatory Drugs}

IDHR to non-steroidal anti-inflammatory drugs (NSAIDs) are extremely common, and it is generally accepted that the large majority of these reactions are independent of $\operatorname{IgE} /$ FceRI cross-linking, but correspond to a pharmacological mechanism caused by the inhibition of cyclo-oxygenase (COX)-1 isoenzyme, resulting in depletion of prostaglandin E2 with unstrained synthesis of cysteinyl leukotrienes and mediator release from basophils, mast cells and eosinophils. Consequently, as displayed in Table 6, the sensitivity of the BAT (about 20-40\%) leaves a lot to be desired regarding diagnosis of IDHR to NSAID hypersensitivity. However, only a minority of IDHR to NSAIDs appear to be 'genuine' IgE-mediated reactions, and in that case, patients appear to react exclusively to a single NSAID family. So far, five publications have reported on BAT in selective hypersensitivity to pyrazolones [73-77]. In these cases, BAT yielded a sensitivity between 42 and $70 \%$ and a specificity of $86-100 \%$. However, one study showed a significant lower sensitivity of the BAT, contradicting the other studies [76]. 
Table 1 Specific IgE to $\beta$-lactam antibiotics

\begin{tabular}{|c|c|c|c|c|c|c|}
\hline Compound & Ref. test & Assay & Sensitivity & Specificity & $N$ & Ref. \\
\hline Various $\beta$-lactams & $\mathrm{H}+\mathrm{ST}$ & CAP-FEIA & $\begin{array}{l}\mathrm{BPO}+\mathrm{AXO} \\
\quad+\text { peni } \mathrm{G}+\mathrm{AMP}: 31.8 \%\end{array}$ & $\begin{array}{l}\text { BPO + AXO + peni } \mathrm{G} \\
\quad+\text { AMP: } 88.6 \%\end{array}$ & 58 & [111] \\
\hline Various $\beta$-lactams & $\mathrm{H}+\mathrm{ST}+\mathrm{DPT}$ & CAP-FEIA & $\begin{array}{l}\text { BPO: } 32 \% \\
\text { AXO: } 43 \% \\
\text { BPO + AXO: } 50 \%\end{array}$ & $\begin{array}{l}\text { BPO: } 98 \% \\
\text { AXO: } 98 \% \\
\text { BPO + AXO: } 96 \%\end{array}$ & 129 & [112] \\
\hline Various $\beta$-lactams & $\mathrm{H}+\mathrm{ST}+\mathrm{DPT}$ & CAP-FEIA & $\begin{array}{l}\text { BPO: } 10-68 \% \\
\text { AXO: } 41-53 \%\end{array}$ & $\begin{array}{l}\text { BPO: } 98 \% \\
\text { AXO: } 95 \%\end{array}$ & 410 & {$[25]$} \\
\hline Various $\beta$-lactams & $\mathrm{H}$ & CAP-FEIA & $37.9 \%$ & $86.7 \%$ & 58 & [113] \\
\hline Various $\beta$-lactams ${ }^{\mathrm{a}}$ & $\mathrm{H}+\mathrm{ST}+\mathrm{DPT}$ & $\begin{array}{l}\text { CAP-FEIA } \\
\text { RAST }^{\mathrm{b}}\end{array}$ & $\begin{array}{l}0-25 \%^{\mathrm{b}} \\
42.9-75 \%^{\mathrm{b}}\end{array}$ & $\begin{array}{l}83.3-100 \%^{\mathrm{b}} \\
66.7-83.3 \%^{\mathrm{b}}\end{array}$ & 45 & {$[21]$} \\
\hline Various $\beta$-lactams & $\mathrm{H}+\mathrm{ST}$ & $\begin{array}{l}\text { CAP-FEIA } \\
\text { CAP-FEIA }\end{array}$ & $\begin{array}{l}85 \%^{\mathrm{c}} \\
44 \%^{\mathrm{d}}\end{array}$ & $\begin{array}{l}54 \%^{\mathrm{c}} \\
80 \%^{\mathrm{d}}\end{array}$ & 176 & [29] \\
\hline Various $\beta$-lactams & $\mathrm{H}+\mathrm{ST}$ & CAP-FEIA & $66 \%$ & $52 \%$ & 293 & [30] \\
\hline
\end{tabular}

$A M P$ ampicillin, $A X O$ amoxicillin, $B P O$ benzyl penicilloyl, CAP-FEIA fluorescence enzyme immunoassay (available from Phadia Thermo Fisher), $D P T$ drug provocation test, $H$ history, $I g E$ immunoglobulin E, $N$ number, peni $G$ penicillin $\mathrm{G}, R A S T$ radio allergo sorbent test, Ref. reference, $S T$ skin test

${ }^{a}$ Home-made assay

b Sensitivity and specificity vary according to clinical manifestations

${ }^{c}$ For a threshold of $0.10 \mathrm{kUA} / \mathrm{L}$

${ }^{\mathrm{d}}$ For a threshold of $0.35 \mathrm{kUA} / \mathrm{L}$

Table 2 BAT in immediate $\beta$-lactam hypersensitivity

\begin{tabular}{|c|c|c|c|c|c|c|}
\hline Stimulus & Ref. test & $\begin{array}{l}\text { Activation } \\
\text { marker }\end{array}$ & $\begin{array}{l}\text { Sensitivity } \\
(\%)\end{array}$ & $\begin{array}{l}\text { Specificity } \\
(\%)\end{array}$ & Number of patients and controls & Ref. \\
\hline$\beta$-Lactam & $\mathrm{H}$ & CD63 & 50 & 93 & 88 & [113] \\
\hline$\beta$-Lactam & $\mathrm{H}+\mathrm{DPT}$ & CD63 & 39 & 93 & 53 & [114] \\
\hline$\beta$-Lactam & $\mathrm{H}+\mathrm{ST}+\mathrm{IgE}+\mathrm{DPT}$ & CD63 & 49 & 91 & 110 & [115] \\
\hline \multirow[t]{2}{*}{ Amoxicillin } & \multirow[t]{2}{*}{$\mathrm{H}+\mathrm{ST}$} & CD203c & 52 & 100 & 41 & [116] \\
\hline & & CD63 & 22 & 79 & & \\
\hline$\beta$-Lactam & $\mathrm{H}$ & CD63 & 50 & $89-97$ & 262 & [117] \\
\hline \multirow[t]{2}{*}{$\beta$-Lactam } & \multirow[t]{2}{*}{$\mathrm{H}+\mathrm{ST}+\mathrm{IgE}$} & CD63-CCR3 & 55 & 100 & 39 & [118] \\
\hline & & CD63-IgE & 53 & & & \\
\hline Amoxicillin & $\mathrm{H}$ & CD63 & 29 & - & 14 patients, no controls & [119] \\
\hline Amoxicillin & $\mathrm{H}+\mathrm{ST}+\mathrm{DPT}$ & CD63 & 50 & - & $\begin{array}{l}61 \text { patients, number of controls not } \\
\text { mentioned }\end{array}$ & [120] \\
\hline Amoxicillin & $\mathrm{H}+\mathrm{ST}$ & CD63 & 50 & - & 30 patients & [121] \\
\hline \multirow[t]{2}{*}{ Cefazolin } & \multirow[t]{2}{*}{$\mathrm{H}+\mathrm{ST}$} & CD63 & 33 & 94 & 16 patients, 17 controls & [122] \\
\hline & & CD203c & 67 & 94 & & \\
\hline
\end{tabular}

$B A T$ basophil activation test, $D P T$ drug provocation test, $H$ history, $I g E$ immunoglobulin E, Ref. reference, $S T$ skin test

\section{Opiates}

Genuine IgE-mediated allergies to opiates (morphine, codeine, pholcodine) remain rare notwithstanding the frequent and universal use of these drugs. Additionally, correct diagnosis is not straightforward, mainly because of uncertainties associated with measurement of drug-sIgE antibodies and skin testing [78]. Recently, it has been suggested that the two commercially available sIgE assays for a Papaver somniferum (poppy seed) extract and morphine can add to the diagnosis of IgE-mediated opiate allergy $[79,80]$. However, using DPT we were unable to confirm these data [81], mainly because of the high prevalence of $\operatorname{sIgE}$ antibodies to these compounds in an allergic population. This observation is highly relevant when facing patients for whom correct identification of the 
Table 3 BAT in immediate quinolone hypersensitivity

\begin{tabular}{|c|c|c|c|c|c|c|}
\hline Stimulus & Ref. test & Activation marker & Sensitivity (\%) & Specificity $(\%)$ & $\begin{array}{l}\text { Number of patients } \\
\text { and controls }\end{array}$ & Ref. \\
\hline Various quinolones & $\mathrm{H}+\mathrm{DPT}$ & CD63 & 0 & - & 4 & {$[37]$} \\
\hline Various quinolones & $\mathrm{H}+\mathrm{ST}+\mathrm{DPT}$ & CD63 & 0 & 100 & 18 & {$[38]$} \\
\hline Various quinolones & $\mathrm{H}$ & CD203c & 100 & 100 & 5 & [41] \\
\hline Various quinolones & $\mathrm{H}+\mathrm{DPT}$ & CD63 & 71 & - & 73 & {$[40]$} \\
\hline Various quinolones & $\mathrm{H}+\mathrm{DPT}$ & CD203c & NA & 100 & 34 & {$[42]$} \\
\hline \multirow[t]{2}{*}{ Moxifloxacin } & \multirow[t]{4}{*}{$\mathrm{H}$} & CD63 & 9.1 & 77.8 & 11 & \multirow[t]{4}{*}{ [39] } \\
\hline & & CD203c & 36.4 & 94.4 & 11 & \\
\hline \multirow[t]{2}{*}{ Ciprofloxacin } & & CD63 & 83.3 & 88.9 & 6 & \\
\hline & & CD203c & 0 & 94.4 & 6 & \\
\hline \multirow[t]{2}{*}{ Moxifloxacin } & \multirow[t]{2}{*}{$\mathrm{H}$} & CD63 & 13.3 & 100 & 24 & \multirow[t]{2}{*}{ Unpu } \\
\hline & & CD203c & 46.7 & 100 & 24 & \\
\hline
\end{tabular}

$B A T$ basophil activation test, $D P T$ drug provocation test, $H$ history, $N A$ not available, Ref. reference, $S T$ skin test, Unpub unpublished data

Table 4 Specific IgE to NMBA and substituted ammonium structures

\begin{tabular}{|c|c|c|c|c|c|c|}
\hline Compound & Ref. test & Assay & Sensitivity & Specificity & $N$ & Ref. \\
\hline \multirow[t]{3}{*}{ Various NMBA } & \multirow[t]{3}{*}{$\mathrm{H}+\mathrm{ST}$} & RIA & PAPPC: $97 \%$ & PAPPC: $97 \%$ & \multirow[t]{3}{*}{75} & \multirow[t]{3}{*}[50]{} \\
\hline & & RIA & MOR: $83 \%$ & NA & & \\
\hline & & RIA & QAS: $86 \%$ & NA & & \\
\hline \multirow[t]{3}{*}{ Various NMBA } & \multirow[t]{3}{*}{$\mathrm{H}+\mathrm{ST}$} & RIA & QAS: $87.9 \%$ & \multirow[t]{3}{*}{ NA } & \multirow[t]{3}{*}{83} & \multirow[t]{3}{*}[51]{} \\
\hline & & RAST & SUC: $66.7 \%$ & & & \\
\hline & & RAST & Alcuronium: $40.7 \%$ & & & \\
\hline \multirow[t]{2}{*}{ Various NMBA } & \multirow[t]{2}{*}{$\mathrm{H}+\mathrm{ST}$} & RIA & MOR: $85 \%$ & \multirow[t]{2}{*}{$98 \%$} & \multirow[t]{2}{*}{118} & \multirow[t]{2}{*}[63]{} \\
\hline & & RIA & NMBA-specific: $52 \%$ & & & \\
\hline \multirow[t]{2}{*}{ Various NMBA } & \multirow[t]{2}{*}{$\mathrm{H}+\mathrm{ST}$} & CAP-FEIA & SUXA: $38.5 \%$ & SUXA: $96.3-99.6 \%$ & \multirow[t]{2}{*}{866} & \multirow[t]{2}{*}[64]{} \\
\hline & & CAP-FEIA & MOR: $67.7 \%$ & MOR: 90-95\% & & \\
\hline \multirow[t]{6}{*}{$\mathrm{ROCU}^{\mathrm{a}}$} & \multirow[t]{6}{*}{$\mathrm{H}+\mathrm{ST}$} & \multirow[t]{6}{*}{ CAP-FEIA } & SUXA: $72 \%^{b}$ & SUXA: $100 \%^{\mathrm{b}}$ & \multirow[t]{6}{*}{82} & \multirow[t]{6}{*}[65]{} \\
\hline & & & SUXA: $60 \%^{\mathrm{c}}$ & SUXA: $100^{\mathrm{c}}$ & & \\
\hline & & & ROCU: $92 \%^{\mathrm{b}}$ & ROCU: $93 \%{ }^{\mathrm{b}}$ & & \\
\hline & & & ROCU: $68 \%^{\mathrm{c}}$ & ROCU: $93 \%^{\mathrm{c}}$ & & \\
\hline & & & MOR: $88 \%$ & MOR: $100 \%$ & & \\
\hline & & & PHOL: $86 \%$ & PHOL: $100 \%$ & & \\
\hline Various $\mathrm{NMBA}^{\mathrm{a}}$ & $\mathrm{H}+\mathrm{ST}$ & CAP-FEIA & $\mathrm{QAM}^{\mathrm{d}}: 87.7 \%$ & QAM $^{\mathrm{d}}: 90.7 \%$ & 168 & [67] \\
\hline \multirow[t]{3}{*}{ ATRA $^{\mathrm{a}}$} & \multirow[t]{3}{*}{$\mathrm{H}+\mathrm{ST}$} & \multirow[t]{3}{*}{ CAP-FEIA } & SUXA: $28.6 \%$ & SUXA: $85.7 \%$ & \multirow[t]{3}{*}{78} & \multirow[t]{3}{*}{ [66] } \\
\hline & & & ATRA: $57.1 \%$ & ATRA: $100 \%$ & & \\
\hline & & & MOR: $14.2 \%$ & MOR: $85.7 \%$ & & \\
\hline
\end{tabular}

ATRA atracurium, CAP-FEIA fluorescence enzyme immunoassay (available from Phadia Thermo Fisher), $H$ history, $I g E$ immunoglobulin E, $N$ number, $N A$ not available, $N A$ not available, $N M B A$ neuromuscular blocking agent, MOR morphine, PAPPC p-aminophenyl phosphoryl choline, $P H O L$ pholcodin, $Q A M$ quaternary ammonium morphine, $Q A S$ quaternary ammonium structure, $R O C$ receiver operating curve, $R A S T$ radio allergosorbent test, $R e f$. reference, RIA radio immunoassay, $R O C U$ rocuronium, $S T$ skin tests, SUC succinyl choline, SUXA suxamethonium

${ }^{a}$ Applying ROC-generated drug-specific thresholds

${ }^{b}$ For a ROC-generated threshold of $0.11 \mathrm{kUA} / \mathrm{L}$ for SUXA and $0.13 \mathrm{kUA} / \mathrm{L}$ for ROCU

${ }^{c}$ For a traditional threshold of $0.35 \mathrm{kUA} / \mathrm{L}$

d 'Optimized' MOR-based assay

causative compound(s) is impeded because of simultaneous intake or administration of different agents, e.g. during general anaesthesia. Erroneous opiate allergy diagnosis might not only entail unnecessary avoidance measures, but also, most importantly, ultimately put patients at risk by overlooking alternative diagnoses such as an allergy to 
Table 5 BAT in immediate NMBA hypersensitivity

\begin{tabular}{lllllll}
\hline Stimulus & Ref. test & Activation marker & Sensitivity (\%) & Specificity (\%) & $N$ & Ref. \\
\hline Various NMBA & $\mathrm{H}$ & CD63 & 64 & 81 & 26 & {$[123]$} \\
Various NMBA & $\mathrm{H}+\mathrm{ST}$ & $\mathrm{CD} 45$ & 43 & 96 & & \\
Various NMBA & $\mathrm{H}$ & $\mathrm{CD} 63$ & 54 & 100 & 56 & {$[12]$} \\
& & $\mathrm{CD} 203 \mathrm{c}$ & 36 & 100 & 31 & {$[124]$} \\
Various NMBA & $\mathrm{H}+\mathrm{ST}$ & $\mathrm{CD63}$ & $36-86^{\mathrm{a}}$ & 93 & & \\
Rocuronium & $\mathrm{H}+\mathrm{ST}$ & $\mathrm{CD} 63$ & $92^{\mathrm{b}}$ & 100 & 92 & {$[125]$} \\
Various NMBA & $\mathrm{H}+\mathrm{ST}+\mathrm{IgE}$ & $\mathrm{CD} 63$ & 60 & 100 & 22 & {$[71]$} \\
Rocuronium & $\mathrm{H}$ & $\mathrm{CD} 63$ & 80 & 96 & 49 & {$[126]$} \\
Various NMBA & $\mathrm{H}+\mathrm{ST}$ & $\mathrm{CD63}$ & 68 & 100 & 104 & {$[68]$} \\
Atracurium & $\mathrm{H}+\mathrm{ST}$ & $\mathrm{CD} 63$ & $71^{\mathrm{c}}$ & 100 & 56 & {$[127]$} \\
\hline
\end{tabular}

$B A T$ basophil activation test, $H$ history, $I g E$ immunoglobulin E, $N$ number of patients and control individuals, $N M B A$ neuromuscular blocking agent, Ref. reference, $S T$ skin test

${ }^{a}$ Increasing sensitivity when only the reactions that occurred during the 3 years were taken into account

b Taking into account the non-responders, sensitivity is $76 \%$

c Taking into account the non-responders, sensitivity is $63 \%$

Table 6 BAT in immediate NSAID hypersensitivity

\begin{tabular}{|c|c|c|c|c|c|c|}
\hline Stimulus & Ref. test & Activation marker & Sensitivity (\%) & Specificity (\%) & $\begin{array}{l}\text { Number of patients } \\
\text { and controls }\end{array}$ & Ref. \\
\hline Metamizol & $\mathrm{H}+\mathrm{DPT}$ & CD63 & 42 & 100 & 56 & {$[73]$} \\
\hline Metamizol & $\mathrm{H}$ & CD63 & 42.3 & 100 & 56 & {$[74]$} \\
\hline Various NSAID & $\mathrm{H}+\mathrm{DPT}$ & CD63 & $15-55$ & $74-100$ & 90 & [128] \\
\hline Diclofenac & $\mathrm{H}$ & CD63 & \multicolumn{2}{|c|}{$\begin{array}{l}\text { No significant difference in CD63 expression } \\
\text { between patients and controls (IgE-independent } \\
\text { basophil degranulation) }\end{array}$} & 26 & [129] \\
\hline Various NSAID & $\mathrm{H}$ & CD63 & 43 & 100 & 72 & [130] \\
\hline Pyrazolones & $\mathrm{H}+\mathrm{IDT}+\mathrm{DPT}$ & CD63 & 55 & 86 & 107 & {$[75]$} \\
\hline ASA & $\mathrm{H}+\mathrm{DPT}$ & $\begin{array}{l}\text { CD63 } \\
\text { CD203c }\end{array}$ & $\begin{array}{l}34 \\
17\end{array}$ & $\begin{array}{l}79 \\
100\end{array}$ & 42 & [131] \\
\hline Diclofenac & & $\begin{array}{l}\text { CD63 } \\
\text { CD203c }\end{array}$ & $\begin{array}{l}17 \\
22\end{array}$ & $\begin{array}{l}92 \\
100\end{array}$ & & \\
\hline ASA & $\mathrm{H}+\mathrm{DPT}$ & $\begin{array}{l}\text { CD63 } \\
\text { CD203c }\end{array}$ & $\begin{array}{l}30 \\
70\end{array}$ & $\begin{array}{l}40 \\
45\end{array}$ & 20 & [132] \\
\hline Diclofenac & $\mathrm{H}+\mathrm{DPT}$ & CD63 & 0 & - & 22 & [133] \\
\hline Aspirin & $\mathrm{H}+\mathrm{DPT}$ & CD63 & $\begin{array}{l}80^{\mathrm{a}} \\
78^{\mathrm{b}}\end{array}$ & $\begin{array}{l}83^{\mathrm{a}} \\
50^{\mathrm{b}}\end{array}$ & 59 & {$[134]$} \\
\hline Various NSAID & $\mathrm{H}+\mathrm{DPT}$ & CD63 & 61 & 91 & 29 & [135] \\
\hline Various NSAID & $\mathrm{H}$ & CD63 & 37 & 90 & 80 & [136] \\
\hline Metamizol & $\mathrm{H}$ & CD63 & 0 & - & 6 patients, no controls & {$[76]$} \\
\hline Metamizol & $\mathrm{H}+\mathrm{ST}$ & CD63 & 70 & 100 & 30 & {$[77]$} \\
\hline Various NSAID & $\mathrm{H}+\mathrm{DPT}$ & CD63 & 100 & 20 & 91 & [137] \\
\hline
\end{tabular}

$A S A$ aspirin acetyl salicylic acid, $B A T$ basophil activation test, $D P T$ drug provocation test, $H$ history, $I D T$ intradermal test, $I g E$ immunoglobulin E, NSAID non-steroidal anti-inflammatory drug, Ref. reference, $S T$ skin test

a For anaphylaxis

${ }^{\mathrm{b}}$ For asthma/rhinoconjunctivitis

rocuronium or suxamethonium. For the time being, the sole in vitro method to document opiate allergy is BAT, as these cells, unlike cutaneous mast cells, are unresponsive to non- specific stimulation with opiates [81, 82] (see also Fig. 2). Moreover, negative BAT, along with negative skin testing for different NMBA and negative provocation tests for the 
structurally almost similar opiates, suggest these drugs are probably safe in pholcodine hypersensitivity [82].

\section{Iodinated Contrast Media}

IDHR to radio contrast media (RCM) have been described, but their prevalence is low and estimated to be between $0.02 \%$ for non-ionic RCM and $0.4 \%$ for ionic RCM. Nonspecific RCM binding to surface receptors on mast cells or basophils can result in direct histamine release and indirect cell activation by means of the complement or kinin cascade. These alternative pathways outnumber the genuine IgE-mediated reactions and might be overlooked by skin testing [83, 84]. IgE-mediated reactions are believed to account for approximately $4 \%$ of the IDHR to RCM. Up to now, three studies reported on the value of BAT in the diagnosis of IDHR to RCM [83, 85, 86]. These studies demonstrate a sensitivity of $46-63 \%$ depending on the chosen threshold, and a specificity of $89-100 \%$. Furthermore, it seems that the results of BAT and skin testing are complementary [83] (Table 7).

\section{Chlorhexidine}

Chlorhexidine, a cationic bisguanide antiseptic and disinfectant, is used as the (di)acetate or (di)glucuronide salt. These chlorhexidine salts can trigger irritant dermatitis, allergic contact dermatitis [87], IDHR (including lifethreatening anaphylaxis) [88-91] and even a combination of both contact dermatitis and IDHR [92]. For a traditional arbitrarily chosen decision threshold of $0.35 \mathrm{kUA} / \mathrm{L}$, the sensitivity of sIgE chlorhexidine varied between 84.2 and $91.6 \%$ and the specificity between 93.7 and $100 \%$. For a ROC-generated threshold of $0.20 \mathrm{kUA} / \mathrm{L}$, sensitivity was 94.1\% and specificity $90.7 \%$ [90, 91]. Like for $\beta$-lactam [29-31] and NMBA [65], raised total IgE levels were shown to have an impact on chlorhexidine sIgE measurement at levels higher than $500 \mathrm{kU} / \mathrm{L}$ and more particularly at levels higher than $2000 \mathrm{kU} / \mathrm{L}$ [91]. Recently, it was demonstrated the optimal sampling time for $\operatorname{sgE}$ chlorhexidine is between 1 and 4 months [93], but $\operatorname{sIgE}$ might persist for years [46].

\section{Miscellaneous}

Bovine gelatin constitutes the active component in certain plasma substitutes and haemostatic sponges, and can be present in various other drugs such as vaccines. Since the first descriptions of the allergenicity of gelatin [94], IgEmediated IDHR to this compound, including fatal anaphylaxis, have been increasingly reported. Today, two distinct types of IgE-mediated bovine gelatin allergy are recognized: genuine gelatin allergy that results from sensitization to the protein part of the molecule; and gelatin allergy resulting from a sensitization to a glycan moiety of the molecule, i.e. galactose- $\alpha[1,3]$-galactose ( $\alpha$-gal) [95-97], as first described by Chung et al. [98] and Commins et al. [99]. To our knowledge, there are no studies that have determined the diagnostic accuracy of sIgE gelatin. However, it is of note that patients with life-threatening anaphylaxis to gelatin as a result of $\alpha$-gal sensitization are generally overlooked by traditional gelatin-sIgE assay and need additional testing including quantification of $\alpha$-galsIgE antibodies and gelatin skin testing [95-97].

\section{Quantification of Serum Tryptase}

Although quantification of acute and baseline serum tryptase does not add to the identification of the culprit, serum tryptase has proven to be of additional value in diagnosing IDHR, mainly to confirm mast cell degranulation and/or to rule out or confirm (clonal) mast cell disorders [100] and mast cell activation syndromes [101]. Currently, in the commercially available tryptase assay, total tryptase is quantified as the sum of continuously secreted baseline tryptase and $\beta$-tryptase released from degranulating mast cells (ImmunoCAP, Thermo Fisher, Uppsala, Sweden). It has been suggested that the recommended decision threshold of $11.4 \mu \mathrm{g} / \mathrm{L}$ be abandoned, since increases in serum tryptase might often be relevant even when values are below this cut-off $[102,103]$.

Table 7 BAT in immediate hypersensitivity to iodinated RCM

\begin{tabular}{lllllll}
\hline Stimulus & Ref. test & Activation marker & Sensitivity (\%) & Specificity (\%) & Number of patients and controls & Ref. \\
\hline Various RCM & H + ST & CD63 & 100 & 100 & 3 patients, unknown number of controls & [85] \\
Various RCM & H + ST & CD63 & $46-62 \%^{\mathrm{a}}$ & $89-100 \%^{\mathrm{a}}$ & 40 & [83] \\
Various RCM & H + ST + DPT & CD63 & 63 & 100 & 28 & [86] \\
\hline
\end{tabular}

$B A T$ basophil activation test, $D P T$ drug provocation test, $H$ history, $R C M$ radiocontrast media, Ref. reference, $S T$ skin test

${ }^{a}$ Depending on the cut-off value 
Furthermore, a new algorithm for interpretation of serum tryptase has been proposed in which the minimal elevation of acute tryptase (within 30-240 min from the event) over baseline ( $24 \mathrm{~h}$ after the acute event) levels is suggested to be clinically relevant, and is calculated as at least $2+1.2 \times$ baseline [104]. Importantly, the sensitivity of this approach seems higher if basal (post-reaction) levels are obtained within 2 months from the acute event [105]. Alternatively, by comparing the two measurements, anaphylaxis could be ruled out even for acute tryptase values of $>11.4 \mu \mathrm{g} / \mathrm{L}$ in cases of baseline hypertryptasaemia due to non-allergic causes [104]. Quantifying baseline tryptase has another additional purpose, as elevated baseline levels might be indicative for underlying (clonal) mast cell disorders [100]. Hypotension without urticaria and angioedema in patients suffering from severe IDHR warrants further diagnostics to rule out a mast cell disorder, particularly in men [106]. Levels of mature tryptase of $>1 \mu \mathrm{g} / \mathrm{L}$ indicate mast cell degranulation. However, this test is not commercially available.

\section{Commentaries and Perspectives}

From this review, it appears that drug-sIgE antibody testing can provide useful information, but can rarely be applied as a solitary diagnostic test to exclude or document IDHR, as these tests lack absolute predictive values. For $\beta$-lactam determinants, the main issue is low sensitivity, which could not be increased without significant loss of specificity [29]. For NMBA, drug-sIgE tests seem to attain acceptable sensitivity and specificity, provided drug-specific cut-offs are applied $[65,91]$. Although quantification of sIgE to morphine appears a reliable biomarker of sensitization to tertiary and quaternary ammonium structures, IgE reactivity to this compound in general and in an allergic population is as high as $5-10 \%$. Therefore, the test should not be applied in isolation to diagnose IDHR to NMBA or opiates. With respect to the unsatisfactory sensitivity of some tests, it has been argued that this observation relates to the time interval elapsed between the acute reaction and testing. Although we agree that late testing can result in lower sensitivity, we do not adhere to the recommendation of the European Network on Drug Allergy and European Academy of Allergy and Clinical Immunology (ENDA/EAACI) Drug Allergy Interest Group. Based upon a single publication about negativation of sIgE to $\beta$-lactam antibiotics [26], in their position paper [107], further use of drug-sIgE is dissuaded when the time interval exceeds 3 years. However, this is not our experience [68], and drug-sIgE may persist as long as 5-30 years [108, 109]. With respect to the low specificity of some tests, it is re-emphasized that correct interpretation of $\mathrm{sIgE}$ results requires taking into account total $\operatorname{IgE}$ values $[29,65,91]$. Whether the introduction of sIgE/total IgE ratios increases specificity [29] remains to be confirmed.

Since the earliest days of BAT, it was obvious that this technique would become an asset in the diagnostic instrumentation to document IDHR, particularly when diagnosis cannot be established by other means. However, additional collaborative large-scale studies are needed to verify whether BAT lives up to its promise, to optimize and harmonize the protocols, to avoid instigation of cynicism and scepticism, and to enable and justify its entrance in routine diagnostic application.

Acknowledgements ALVG is a fellow of the FWO $(1113617 \mathrm{~N})$. DGE is a senior clinical researcher of the FWO $(1800614 \mathrm{~N})$.

\section{Compliance with Ethical Standards}

IID, EAM, ALVG, KC, AU, MF, VS, CHB, CM, MMH, LSDC and DGE declare they have no conflict of interest. No funding for this review was provided.

Open Access This article is distributed under the terms of the Creative Commons Attribution-NonCommercial 4.0 International License (http://creativecommons.org/licenses/by-nc/4.0/), which permits any noncommercial use, distribution, and reproduction in any medium, provided you give appropriate credit to the original author(s) and the source, provide a link to the Creative Commons license, and indicate if changes were made.

\section{References}

1. Demoly P, Romano A, Botelho C, Bousquet-Rouanet L, Gaeta F, Silva R, et al. Determining the negative predictive value of provocation tests with beta-lactams. Allergy. 2010;65(3):327-32.

2. McNeil BD, Pundir P, Meeker S, Han L, Undem BJ, Kulka M, et al. Identification of a mast-cell-specific receptor crucial for pseudo-allergic drug reactions. Nature. 2015;519(7542):237-41.

3. Spoerl D, D'Incau S, Roux-Lombard P, Harr T, Czarnetzki C. Non-IgE-dependent hypersensitivity to rocuronium reversed by sugammadex: report of three cases and hypothesis on the underlying mechanism. Int Arch Allergy Immunol. 2016;169(4):256-62.

4. Ishizaka K, Ishizaka T. Physicochemical properties of reaginic antibody. 1. Association of reaginic activity with an immunoglobulin other than gammaA- or gammaG-globulin. J Allergy. 1966;37(3):169-85.

5. Johansson SG, Bennich H. Immunological studies of an atypical (myeloma) immunoglobulin. Immunology. 1967;13(4):381-94.

6. Johansson SG. In vitro diagnosis of reagin-mediated allergic diseases. Allergy. 1978;33(6):292-8.

7. Hamilton RG. Clinical laboratory assessment of immediate-type hypersensitivity. J Allergy Clin Immunol. 2010;125(2 Suppl 2):S284-96

8. Knol EF, Mul FP, Jansen H, Calafat J, Roos D. Monitoring human basophil activation via CD63 monoclonal antibody 435 . J Allergy Clin Immunol. 1991;88(3 Pt 1):328-38.

9. Bridts CH, Sabato V, Mertens C, Hagendorens MM, De Clerck LS, Ebo DG. Flow cytometric allergy diagnosis: basophil activation techniques. Methods Mol Biol. 2014;1192:147-59. 
10. Buhring HJ, Seiffert M, Giesert C, Marxer A, Kanz L, Valent P, et al. The basophil activation marker defined by antibody 97A6 is identical to the ectonucleotide pyrophosphatase/phosphodiesterase 3. Blood. 2001;97(10):3303-5.

11. Buhring HJ, Streble A, Valent P. The basophil-specific ectoenzyme E-NPP3 (CD203c) as a marker for cell activation and allergy diagnosis. Int Arch Allergy Immunol. 2004;133(4):317-29.

12. Monneret G, Benoit Y, Debard AL, Gutowski MC, Topenot I, Bienvenu J. Monitoring of basophil activation using CD63 and CCR3 in allergy to muscle relaxant drugs. Clin Immunol (Orlando, Fla). 2002;102(2):192-9.

13. Chirumbolo S, Ortolani R, Vella A. CCR3 as a single selection marker compared to CD123/HLADR to isolate basophils in flow cytometry: some comments. Cytom Part A: J Int Soc Anal Cytol. 2011;79(2):102-6.

14. Hausmann OV, Gentinetta T, Fux M, Ducrest S, Pichler WJ, Dahinden CA. Robust expression of CCR3 as a single basophil selection marker in flow cytometry. Allergy. 2011;66(1):85-91.

15. Chirumbolo S. Major pitfalls in BAT performance may be caused by gating protocols and CD63\% cut off evaluation. Cytom Part A: J Int Soc Anal Cytol. 2014;85(5):382-5.

16. MacGlashan D Jr. Expression of CD203c and CD63 in human basophils: relationship to differential regulation of piecemeal and anaphylactic degranulation processes. Clin Exp Allergy: J Br Soc Allergy Clin Immunol. 2010;40(9):1365-77.

17. Sabato V, Verweij MM, Bridts CH, Levi-Schaffer F, Gibbs BF, De Clerck LS, et al. CD300a is expressed on human basophils and seems to inhibit IgE/FcepsilonRI-dependent anaphylactic degranulation. Cytom Part B Clin Cytom. 2012;82(3):132-8.

18. Ebo DG, Dombrecht EJ, Bridts CH, Aerts NE, de Clerck LS, Stevens WJ. Combined analysis of intracellular signalling and immunophenotype of human peripheral blood basophils by flow cytometry: a proof of concept. Clin Exp Allergy: J Br Soc Allergy Clin Immunol. 2007;37(11):1668-75.

19. Verweij MM, Sabato V, Nullens S, Bridts CH, De Clerck LS, Stevens WJ, et al. STAT5 in human basophils: IL-3 is required for its FcepsilonRI-mediated phosphorylation. Cytom Part B Clin Cytom. 2012;82(2):101-6.

20. Ebo DG, Bridts CH, Mertens CH, Hagendorens MM, Stevens WJ, De Clerck LS. Analyzing histamine release by flow cytometry (HistaFlow): a novel instrument to study the degranulation patterns of basophils. J Immunol Methods. 2012;375(1-2):30-8.

21. Fontaine C, Mayorga C, Bousquet PJ, Arnoux B, Torres MJ, Blanca $\mathrm{M}$, et al. Relevance of the determination of serumspecific IgE antibodies in the diagnosis of immediate beta-lactam allergy. Allergy. 2007;62(1):47-52.

22. Silva R, Cruz L, Botelho C, Castro E, Cadinha S, Castel-Branco $\mathrm{MG}$, et al. Immediate hypersensitivity to penicillins with negative skin tests-the value of specific IgE. Eur Ann Allergy Clin Immunol. 2009;41(4):117-9.

23. Qiao HL, Li Z, Yang J, Tian X, Gao N, Jia LJ. Hypersensitivity reactions to penicillins: studies in a group of patients with negative benzylpenicillin $\mathrm{G}$ skin test. J Clin Pharm Ther. 2009;34(3):249-54.

24. Hjortlund J, Mortz CG, Skov PS, Bindslev-Jensen C. Diagnosis of penicillin allergy revisited: the value of case history, skin testing, specific IgE and prolonged challenge. Allergy. 2013;68(8):1057-64.

25. Torres MJ, Romano A, Mayorga C, Moya MC, Guzman AE, Reche $\mathrm{M}$, et al. Diagnostic evaluation of a large group of patients with immediate allergy to penicillins: the role of skin testing. Allergy. 2001;56(9):850-6.

26. Fernandez TD, Torres MJ, Blanca-Lopez N, Rodriguez-Bada JL, Gomez E, Canto G, et al. Negativization rates of $\operatorname{IgE}$ radioimmunoassay and basophil activation test in immediate reactions to penicillins. Allergy. 2009;64(2):242-8.

27. Macy E, Goldberg B, Poon KY. Use of commercial anti-penicillin IgE fluorometric enzyme immunoassays to diagnose penicillin allergy. Ann Allergy Asthma Immunol: Off Publ Am Coll Allergy Asthma Immunol. 2010;105(2):136-41.

28. Aberer W, Zidarn M, Kranke B. IgE antibodies to penicillin are indicative for but not conclusive proof of penicillin allergy. Br J Dermatol. 2006;154(6):1209-10.

29. Vultaggio A, Matucci A, Virgili G, Rossi O, Fili L, Parronchi P, et al. Influence of total serum IgE levels on the in vitro detection of beta-lactams-specific IgE antibodies. Clin Exp Allergy: J Br Soc Allergy Clin Immunol. 2009;39(6):838-44.

30. Vultaggio A, Virgili G, Gaeta F, Romano A, Maggi E, Matucci A. High serum beta-lactams specific/total $\mathrm{IgE}$ ratio is associated with immediate reactions to beta-lactams antibiotics. PLoS One. 2015;10(4):e0121857.

31. Johansson SG, Adedoyin J, van Hage M, Gronneberg R, Nopp A. False-positive penicillin immunoassay: an unnoticed common problem. J Allergy Clin Immunol. 2013;132(1):235-7.

32. Macy E. Penicillin allergy: optimizing diagnostic protocols, public health implications, and future research needs. Curr Opin Allergy Clin Immunol. 2015;15(4):308-13.

33. Mirakian R, Leech SC, Krishna MT, Richter AG, Huber PA, Farooque $\mathrm{S}$, et al. Management of allergy to penicillins and other beta-lactams. Clin Exp Allergy: J Br Soc Allergy Clin Immunol. 2015;45(2):300-27.

34. Broz P, Harr T, Hecking C, Grize L, Scherer K, Jaeger KA, et al. Nonirritant intradermal skin test concentrations of ciprofloxacin, clarithromycin, and rifampicin. Allergy. 2012;67(5):647-52.

35. Empedrad R, Darter AL, Earl HS, Gruchalla RS. Nonirritating intradermal skin test concentrations for commonly prescribed antibiotics. J Allergy Clin Immunol. 2003;112(3):629-30.

36. Uyttebroek AP, Sabato V, Bridts CH, De Clerck LS, Ebo DG. Moxifloxacin hypersensitivity: uselessness of skin testing. J Allergy Clin Immunol Pract. 2015;3(3):443-5.

37. Seitz CS, Brocker EB, Trautmann A. Diagnostic testing in suspected fluoroquinolone hypersensitivity. Clin Exp Allergy: J Br Soc Allergy Clin Immunol. 2009;39(11):1738-45.

38. Lobera T, Audicana MT, Alarcon E, Longo N, Navarro B, Munoz D. Allergy to quinolones: low cross-reactivity to levofloxacin. J Investig Allergol Clin Immunol. 2010;20(7):607-11.

39. Fernandez TD, Ariza A, Palomares F, Montanez MI, Salas M, Martin-Serrano A, et al. Hypersensitivity to fluoroquinolones: the expression of basophil activation markers depends on the clinical entity and the culprit fluoroquinolone. Medicine. 2016;95(23):e3679.

40. Aranda A, Mayorga C, Ariza A, Dona I, Rosado A, BlancaLopez $\mathrm{N}$, et al. In vitro evaluation of IgE-mediated hypersensitivity reactions to quinolones. Allergy. 2011;66(2):247-54.

41. Ben Said B, Berard F, Bienvenu J, Nicolas JF, Rozieres A. Usefulness of basophil activation tests for the diagnosis of IgEmediated allergy to quinolones. Allergy. 2010;65(4):535-6.

42. Rouzaire P, Nosbaum A, Denis L, Bienvenu F, Berard F, Cozon $\mathrm{G}$, et al. Negativity of the basophil activation test in quinolone hypersensitivity: a breakthrough for provocation test decisionmaking. Int Arch Allergy Immunol. 2012;157(3):299-302.

43. Manfredi M, Severino M, Testi S, Macchia D, Ermini G, Pichler WJ, et al. Detection of specific IgE to quinolones. J Allergy Clin Immunol. 2004;113(1):155-60.

44. Mertes PM, Alla F, Trechot P, Auroy Y, Jougla E. Anaphylaxis during anesthesia in France: an 8-year national survey. J Allergy Clin Immunol. 2011;128(2):366-73.

45. Dong SW, Mertes PM, Petitpain N, Hasdenteufel F, Malinovsky JM. Hypersensitivity reactions during anesthesia. Results from the ninth French survey (2005-2007). Minerva Anestesiol. 2012;78(8):868-78. 
46. Leysen J, De Witte L, Bridts CH, Ebo DG. Anaphylaxis during general anaesthesia: a 10-year survey at the University Hospital Antwerp. Proc Belg R Acad Med. 2013;2:88-100.

47. Antunes J, Kochuyt AM, Ceuppens JL. Perioperative allergic reactions: experience in a Flemish referral centre. Allergol Immunopathol. 2014;42(4):348-54.

48. Low AE, McEwan JC, Karanam S, North J, Kong KL. Anaesthesia-associated hypersensitivity reactions: seven years' data from a British bi-specialty clinic. Anaesthesia. 2016;71(1):76-84.

49. Mertes PM, Malinovsky JM, Jouffroy L, Aberer W, Terreehorst I, Brockow K, et al. Reducing the risk of anaphylaxis during anesthesia: 2011 updated guidelines for clinical practice. J Investig Allergol Clin Immunol. 2011;21(6):442-53.

50. Guilloux L, Ricard-Blum S, Ville G, Motin J. A new radioimmunoassay using a commercially available solid support for the detection of IgE antibodies against muscle relaxants. J Allergy Clin Immunol. 1992;90(2):153-9.

51. Gueant JL, Mata E, Monin B, Moneret-Vautrin DA, Kamel L, Nicolas JP, et al. Evaluation of a new reactive solid phase for radioimmunoassay of serum specific IgE against muscle relaxant drugs. Allergy. 1991;46(6):452-8.

52. Harle DG, Baldo BA, Fisher MM. Immunoassays employing substituted ammonium compounds other than neuromuscular blocking drugs to increase the detection of $\operatorname{IgE}$ antibodies to these drugs. Mol Immunol. 1990;27(10):1039-45.

53. Baldo BA, Fisher MM. Diagnosis of IgE-dependent anaphylaxis to neuromuscular blocking drugs, thiopentone and opioids. Ann Fr Anesth Reanim. 1993;12(2):173-81.

54. Baldo BA, Fisher MM. Substituted ammonium ions as allergenic determinants in drug allergy. Nature. 1983;306(5940):262-4.

55. Didier A, Cador D, Bongrand P, Furstoss R, Fourneron P, Senft $\mathrm{M}$, et al. Role of the quaternary ammonium ion determinants in allergy to muscle relaxants. J Allergy Clin Immunol. 1987;79(4):578-84.

56. Laxenaire MC, Mertes PM. Anaphylaxis during anaesthesia. Results of a two-year survey in France. $\mathrm{Br} \mathrm{J}$ Anaesth. 2001;87(4):549-58.

57. Mertes PM, Laxenaire MC, Alla F. Anaphylactic and anaphylactoid reactions occurring during anesthesia in France in 1999-2000. Anesthesiology. 2003;99(3):536-45.

58. Mertes PM, Laxenaire MC. Adverse reactions to neuromuscular blocking agents. Curr Allergy Asthma Rep. 2004;4(1):7-16.

59. Mertes PM, Laxenaire MC, Lienhart A, Aberer W, Ring J, Pichler WJ, et al. Reducing the risk of anaphylaxis during anaesthesia: guidelines for clinical practice. J Investig Allergol Clin Immunol. 2005;15(2):91-101.

60. Harle DG, Baldo BA, Fisher MM. Detection of IgE antibodies to suxamethonium after anaphylactoid reactions during anaesthesia. Lancet (London, England). 1984;1(8383):930-2.

61. Harle DG, Baldo BA, Fisher MM. Assays for, and cross-reactivities of, $\mathrm{IgE}$ antibodies to the muscle relaxants gallamine, decamethonium and succinylcholine (suxamethonium). J Immunol Methods. 1985;78(2):293-305.

62. Harboe T, Guttormsen AB, Irgens A, Dybendal T, Florvaag E. Anaphylaxis during anesthesia in Norway: a 6-year single-center follow-up study. Anesthesiology. 2005;102(5):897-903.

63. Fisher MM, Baldo BA. Immunoassays in the diagnosis of anaphylaxis to neuromuscular blocking drugs: the value of morphine for the detection of IgE antibodies in allergic subjects. Anaesth Intensive Care. 2000;28(2):167-70.

64. Florvaag E, Johansson SG, Oman H, Venemalm L, Degerbeck F, Dybendal T, et al. Prevalence of IgE antibodies to morphine. Relation to the high and low incidences of NMBA anaphylaxis in Norway and Sweden, respectively. Acta Anaesthesiol Scand. 2005;49(4):437-44.

65. Ebo DG, Venemalm L, Bridts CH, Degerbeck F, Hagberg H, De Clerck LS, et al. Immunoglobulin $\mathrm{E}$ antibodies to rocuronium: a new diagnostic tool. Anesthesiology. 2007;107(2):253-9.

66. Uyttebroek AP, Sabato V, Bridts CH, De Clerck LS, Ebo DG. Immunoglobulin $\mathrm{E}$ antibodies to atracurium: a new diagnostic tool? Clin Exp Allergy: $\mathrm{J}$ Br Soc Allergy Clin Immunol. 2015;45(2):485-7.

67. Laroche D, Chollet-Martin S, Leturgie P, Malzac L, Vergnaud $\mathrm{MC}$, Neukirch $\mathrm{C}$, et al. Evaluation of a new routine diagnostic test for immunoglobulin $\mathrm{E}$ sensitization to neuromuscular blocking agents. Anesthesiology. 2011;114(1):91-7.

68. Leysen J, Bridts CH, De Clerck LS, Vercauteren M, Lambert J, Weyler JJ, et al. Allergy to rocuronium: from clinical suspicion to correct diagnosis. Allergy. 2011;66(8):1014-9.

69. Leysen J, Uyttebroek A, Sabato V, Bridts CH, De Clerck LS, Ebo DG. Predictive value of allergy tests for neuromuscular blocking agents: tackling an unmet need. Clin Exp Allergy: J Br Soc Allergy Clin Immunol. 2014;44(8):1069-75.

70. Florvaag E, Johansson SG, Oman H, Harboe T, Nopp A. Pholcodine stimulates a dramatic increase of $\operatorname{IgE}$ in IgE-sensitized individuals. A pilot study. Allergy. 2006;61(1):49-55.

71. Ebo DG, Bridts CH, Hagendorens MM, Mertens CH, De Clerck LS, Stevens WJ. Flow-assisted diagnostic management of anaphylaxis from rocuronium bromide. Allergy. 2006;61(8):935-9.

72. Uyttebroek AP, Sabato V, Leysen J, Bridts CH, De Clerck LS, Ebo DG. Flowcytometric diagnosis of atracurium-induced anaphylaxis. Allergy. 2014;69(10):1324-32.

73. Gamboa PM, Sanz ML, Caballero MR, Antepara I, Urrutia I, Jauregui I, et al. Use of CD63 expression as a marker of in vitro basophil activation and leukotriene determination in metamizol allergic patients. Allergy. 2003;58(4):312-7.

74. Sanz ML, Garcia MC, Caballero MR, Dieguez I, Gamboa PM. Basophil activation test in the diagnosis of allergy to medicines. Anales del sistema sanitario de Navarra. 2003;26(Suppl 2):39-47.

75. Gomez E, Blanca-Lopez N, Torres MJ, Requena G, Rondon C, Canto $\mathrm{G}$, et al. Immunoglobulin E-mediated immediate allergic reactions to dipyrone: value of basophil activation test in the identification of patients. Clin Exp Allergy: J Br Soc Allergy Clin Immunol. 2009;39(8):1217-24.

76. Couto M, Gaspar A, Piedade S, Arede C, Menezes M, Sousa MJ, et al. IgE-mediated metamizol allergy and the usefulness of the cellular allergen stimulation test. Eur Ann Allergy Clin Immunol. 2012;44(3):113-6.

77. Hagau N, Longrois D, Petrisor C. Threshold for positivity and optimal dipyrone concentration in flow cytometry-assisted basophil activation test. Allergy Asthma Immunol Res. 2013;5(6):383-8.

78. Baldo BA, Pham NH. Histamine-releasing and allergenic properties of opioid analgesic drugs: resolving the two. Anaesth Intensive Care. 2012;40(2):216-35.

79. Armentia A, Ruiz-Munoz P, Quesada JM, Postigo I, Herrero M, Martin-Gil FJ, et al. Clinical value of morphine, pholcodine and poppy seed IgE assays in drug-abusers and allergic people. Allergol Immunopathol. 2013;41(1):37-44.

80. Armentia A, Pineda F, Palacios R, Martin-Gil FJ, Miguel AS, Arenal JJ, et al. Utility of opium seed extract tests in preventing hypersensitivity reactions during surgery. Allergol Immunopathol. 2014;42(1):56-63.

81. Van Gasse AL, Hagendorens MM, Sabato V, Bridts CH, De Clerck LS, Ebo DG. IgE to poppy seed and morphine are not useful tools to diagnose opiate allergy. J Allergy Clin Immunol Pract. 2015;3(3):396-9. 
82. Leysen J, De Witte L, Sabato V, Faber M, Hagendorens M, Bridts $\mathrm{C}$, et al. IgE-mediated allergy to pholcodine and crossreactivity to neuromuscular blocking agents: lessons from flow cytometry. Cytom Part B Clin Cytom. 2013;84(2):65-70.

83. Pinnobphun P, Buranapraditkun S, Kampitak T, Hirankarn N, Klaewsongkram J. The diagnostic value of basophil activation test in patients with an immediate hypersensitivity reaction to radiocontrast media. Ann Allergy Asthma Immunol: Off Publ Am Coll Allergy Asthma Immunol. 2011;106(5):387-93.

84. Philipse E, Sabato V, Bridts C, De Clerck L, Ebo D. Basophil activation in the diagnosis of life-threatening hypersensitivity reaction to iodinated contrast media: a case report. Acta Clin Belg. 2013;68(2):140-2.

85. Trcka J, Schmidt C, Seitz CS, Brocker EB, Gross GE, Trautmann A. Anaphylaxis to iodinated contrast material: nonallergic hypersensitivity or IgE-mediated allergy? AJR Am J Roentgenol. 2008;190(3):666-70.

86. Salas M, Gomez F, Fernandez TD, Dona I, Aranda A, Ariza A, et al. Diagnosis of immediate hypersensitivity reactions to radiocontrast media. Allergy. 2013;68(9):1203-6.

87. Opstrup MS, Johansen JD, Zachariae C, Garvey LH. Contact allergy to chlorhexidine in a tertiary dermatology clinic in Denmark. Contact Dermat. 2016;74(1):29-36.

88. Ebo DG, Bridts CH, Stevens WJ. IgE-mediated anaphylaxis from chlorhexidine: diagnostic possibilities. Contact Dermat. 2006;55(5):301-2.

89. Faber M, Leysen J, Bridts C, Sabato V, De Clerck LS, Ebo DG. Allergy to chlorhexidine: beware of the central venous catheter. Acta Anaesthesiol Belg. 2012;63(4):191-4.

90. Opstrup MS, Malling HJ, Kroigaard M, Mosbech H, Skov PS, Poulsen LK, et al. Standardized testing with chlorhexidine in perioperative allergy - a large single-centre evaluation. Allergy. 2014;69(10):1390-6.

91. Anderson J, Rose M, Green S, Fernando SL. The utility of specific IgE testing to chlorhexidine in the investigation of perioperative adverse reactions. Ann Allergy Asthma Immunol: Off Publ Am Coll Allergy Asthma Immunol. 2015;114(5):425.e1-426.e1.

92. Ebo DG, Stevens WJ, Bridts CH, Matthieu L. Contact allergic dermatitis and life-threatening anaphylaxis to chlorhexidine. J Allergy Clin Immunol. 1998;101(1 Pt 1):128-9.

93. Opstrup MS, Poulsen LK, Malling HJ, Jensen BM, Garvey LH. Dynamics of plasma levels of specific IgE in chlorhexidine allergic patients with and without accidental re-exposure. Clin Exp Allergy. 2016;46(8):1090-8.

94. Ratner B, Crawford LV. The allergenicity of gelatin. Int Arch Allergy Appl Immunol. 1955;6(4-6):370-1.

95. Mullins RJ, James H, Platts-Mills TA, Commins S. Relationship between red meat allergy and sensitization to gelatin and galactose-alpha-1,3-galactose. J Allergy Clin Immunol. 2012;129(5):1334.e1-1342.e1.

96. Ebo DG, Faber M, Sabato V, Leysen J, Gadisseur A, Bridts CH, et al. Sensitization to the mammalian oligosaccharide galactosealpha-1,3-galactose (alpha-gal): experience in a Flemish case series. Acta Clin Belg. 2013;68(3):206-9.

97. Uyttebroek A, Sabato V, Bridts CH, De Clerck LS, Ebo DG. Anaphylaxis to succinylated gelatin in a patient with a meat allergy: galactose-alpha(1, 3)-galactose (alpha-gal) as antigenic determinant. J Clin Anesth. 2014;26(7):574-6.

98. Chung CH, Mirakhur B, Chan E, Le QT, Berlin J, Morse M, et al. Cetuximab-induced anaphylaxis and $\operatorname{IgE}$ specific for galactose-alpha-1,3-galactose. $\mathrm{N}$ Engl J Med. 2008;358(11):1109-17.

99. Commins SP, Satinover SM, Hosen J, Mozena J, Borish L, Lewis BD, et al. Delayed anaphylaxis, angioedema, or urticaria after consumption of red meat in patients with $\operatorname{IgE}$ antibodies specific for galactose-alpha-1,3-galactose. J Allergy Clin Immunol. 2009;123(2):426-33.

100. Bonadonna P, Pagani M, Aberer W, Bilo MB, Brockow K, Oude Elberink $\mathrm{H}$, et al. Drug hypersensitivity in clonal mast cell disorders: ENDA/EAACI position paper. Allergy. 2015;70(7):755-63.

101. Akin C. Mast cell activation syndromes presenting as anaphylaxis. Immunol Allergy Clin N Am. 2015;35(2):277-85.

102. Borer-Reinhold M, Haeberli G, Bitzenhofer M, Jandus P, Hausmann O, Fricker M, et al. An increase in serum tryptase even below $11.4 \mathrm{ng} / \mathrm{mL}$ may indicate a mast cell-mediated hypersensitivity reaction: a prospective study in Hymenoptera venom allergic patients. Clin Exp Allergy: J Br Soc Allergy. Clin Immunol. 2011;41(12):1777-83.

103. Garvey LH, Bech B, Mosbech H, Kroigaard M, Belhage B, Husum $\mathrm{B}$, et al. Effect of general anesthesia and orthopedic surgery on serum tryptase. Anesthesiology. 2010;112(5):1184-9.

104. Sprung J, Weingarten TN, Schwartz LB. Presence or absence of elevated acute total serum tryptase by itself is not a definitive marker for an allergic reaction. Anesthesiology. 2015;122(3):713-4.

105. De Schryver S, Halbrich M, Clarke A, La Vieille S, Eisman H, Alizadehfar R, et al. Tryptase levels in children presenting with anaphylaxis: temporal trends and associated factors. J Allergy Clin Immunol. 2016;137(4):1138-42.

106. Alvarez-Twose I, Gonzalez-de-Olano D, Sanchez-Munoz L, Matito A, Jara-Acevedo M, Teodosio C, et al. Validation of the REMA score for predicting mast cell clonality and systemic mastocytosis in patients with systemic mast cell activation symptoms. Int Arch Allergy Immunol. 2012;157(3):275-80.

107. Mayorga C, Celik G, Rouzaire P, Whitaker P, Bonadonna P, Rodrigues-Cernadas $\mathrm{J}$, et al. In vitro tests for drug hypersensitivity reactions: an ENDA/EAACI Drug Allergy Interest Group position paper. Allergy. 2016;71(8):1103-34.

108. Fisher MM, Baldo BA. Persistence of allergy to anaesthetic drugs. Anaesth Intensive Care. 1992;20(2):143-6.

109. Romano A, Gaeta F, Valluzzi RL, Zaffiro A, Caruso C, Quaratino D. Natural evolution of skin-test sensitivity in patients with IgE-mediated hypersensitivity to cephalosporins. Allergy. 2014;69(6):806-9.

110. Mangodt EA, Van Gasse AL, Decuyper I, Uyttebroek A, Faber MA, Sabato V, et al. In vitro diagnosis of immediate drug hypersensitivity: should we go with the flow? Int Arch Allergy Immunol. 2015;168(1):3-12.

111. Sanz ML, Garcia BE, Prieto I, Tabar A, Oehling A. Specific IgE determination in the diagnosis of beta-lactam allergy. J Investig Allergol Clin Immunol. 1996;6(2):89-93.

112. Blanca M, Mayorga C, Torres MJ, Reche M, Moya MC, Rodriguez JL, et al. Clinical evaluation of Pharmacia CAP System RAST FEIA amoxicilloyl and benzylpenicilloyl in patients with penicillin allergy. Allergy. 2001;56(9):862-70.

113. Sanz ML, Gamboa PM, Antepara I, Uasuf C, Vila L, GarciaAviles $\mathrm{C}$, et al. Flow cytometric basophil activation test by detection of CD63 expression in patients with immediate-type reactions to betalactam antibiotics. Clin Exp Allergy: J Br Soc Allergy Clin Immunol. 2002;32(2):277-86.

114. Gamboa PM, Garcia-Aviles MC, Urrutia I, Antepara I, Esparza $\mathrm{R}$, Sanz ML. Basophil activation and sulfidoleukotriene production in patients with immediate allergy to betalactam antibiotics and negative skin tests. J Investig Allergol Clin Immunol. 2004;14(4):278-83.

115. Torres MJ, Padial A, Mayorga C, Fernandez T, Sanchez-Sabate E, Cornejo-Garcia JA, et al. The diagnostic interpretation of basophil activation test in immediate allergic reactions to betalactams. Clin Exp Allergy: J Br Soc Allergy Clin Immunol. 2004;34(11):1768-75. 
116. Abuaf N, Rostane H, Rajoely B, Gaouar H, Autegarden JE, Leynadier $\mathrm{F}$, et al. Comparison of two basophil activation markers CD63 and CD203c in the diagnosis of amoxicillin allergy. Clin Exp Allergy: J Br Soc Allergy Clin Immunol. 2008;38(6):921-8.

117. De Week AL, Sanz ML, Gamboa PM, Aberer W, Sturm G, Bilo $\mathrm{MB}$, et al. Diagnosis of immediate-type beta-lactam allergy in vitro by flow-cytometric basophil activation test and sulfidoleukotriene production: a multicenter study. J Investig Allergol Clin Immunol. 2009;19(2):91-109.

118. Eberlein B, Leon Suarez I, Darsow U, Rueff F, Behrendt H, Ring J. A new basophil activation test using CD63 and CCR3 in allergy to antibiotics. Clin Exp Allergy: J Br Soc Allergy Clin Immunol. 2010;40(3):411-8.

119. Garcia-Ortega P, Marin A. Usefulness of the basophil activation test (BAT) in the diagnosis of life-threatening drug anaphylaxis. Allergy. 2010;65(9):1204.

120. Torres MJ, Ariza A, Fernandez J, Moreno E, Laguna JJ, Montanez MI, et al. Role of minor determinants of amoxicillin in the diagnosis of immediate allergic reactions to amoxicillin. Allergy. 2010;65(5):590-6.

121. Torres MJ, Romano A, Blanca-Lopez N, Dona I, Canto G, Ariza $A$, et al. Immunoglobulin E-mediated hypersensitivity to amoxicillin: in vivo and in vitro comparative studies between an injectable therapeutic compound and a new commercial compound. Clin Exp Allergy: J Br Soc Allergy Clin Immunol. 2011;41(11):1595-601.

122. Uyttebroek AP, Sabato V, Cop N, Decuyper II, Faber MA, Bridts $\mathrm{CH}$, et al. Diagnosing cefazolin hypersensitivity: Lessons from dual-labeling flow cytometry. J Allergy Clin Immunol Pract. 2016;4(6):1243-5.

123. Abuaf N, Rajoely B, Ghazouani E, Levy DA, Pecquet C, Chabane $\mathrm{H}$, et al. Validation of a flow cytometric assay detecting in vitro basophil activation for the diagnosis of muscle relaxant allergy. J Allergy Clin Immunol. 1999;104(2 Pt 1):411-8.

124. Sudheer PS, Hall JE, Read GF, Rowbottom AW, Williams PE. Flow cytometric investigation of peri-anaesthetic anaphylaxis using CD63 and CD203c. Anaesthesia. 2005;60(3):251-6.

125. Kvedariene V, Kamey S, Ryckwaert Y, Rongier M, Bousquet J, Demoly P, et al. Diagnosis of neuromuscular blocking agent hypersensitivity reactions using cytofluorimetric analysis of basophils. Allergy. 2006;61(3):311-5.

126. Sainte-Laudy J, Orsel I. Interest of a new flow cytometric protocol applied to diagnosis and prevention of per anaesthetic accidents induced by neuromuscular blockers. Rev Fr Allergol. 2008;48:5.
127. Hagau N, Gherman-Ionica N, Sfichi M, Petrisor C. Threshold for basophil activation test positivity in neuromuscular blocking agents hypersensitivity reactions. Allergy Asthma Clin Immunol: Off J Can Soc Allergy Clin Immunol. 2013;9(1):42.

128. Gamboa P, Sanz ML, Caballero MR, Urrutia I, Antepara I, Esparza R, et al. The flow-cytometric determination of basophil activation induced by aspirin and other non-steroidal anti-inflammatory drugs (NSAIDs) is useful for in vitro diagnosis of the NSAID hypersensitivity syndrome. Clin Exp Allergy: $\mathrm{J} \mathrm{Br}$ Soc Allergy Clin Immunol. 2004;34(9):1448-57.

129. Malbran A, Yeyati E, Rey GL, Galassi N. Diclofenac induces basophil degranulation without increasing CD63 expression in sensitive patients. Clin Exp Immunol. 2007;147(1):99-105.

130. Rodriguez-Trabado A, Camara-Hijon C, Ramos-Cantarino A, Porcel-Carreno SL, Jimenez-Timon S, Pereira-Navarro G, et al. Basophil activation test for the in vitro diagnosis of nonsteroidal anti-inflammatory drug hypersensitivity. Allergy Asthma Proc: Off J Reg State Allergy Soc. 2008;29(3):241-9.

131. Bavbek S, Ikinciogullari A, Dursun AB, Guloglu D, Arikan M, Elhan AH, et al. Upregulation of CD63 or CD203c alone or in combination is not sensitive in the diagnosis of nonsteroidal anti-inflammatory drug intolerance. Int Arch Allergy Immunol. 2009; 150(3):261-70.

132. Celik GE, Schroeder JT, Hamilton RG, Saini SS, Adkinson NF. Effect of in vitro aspirin stimulation on basophils in patients with aspirin-exacerbated respiratory disease. Clin Exp Allergy: J Br Soc Allergy Clin Immunol. 2009;39(10):1522-31.

133. Harrer A, Lang R, Grims R, Braitsch M, Hawranek T, Aberer W, et al. Diclofenac hypersensitivity: antibody responses to the parent drug and relevant metabolites. PLoS One. 2010;5(10):e13707.

134. Korosec P, Mavsar N, Bajrovic N, Silar M, Mrhar A, Kosnik M. Basophil responsiveness and clinical picture of acetylsalicylic acid intolerance. Int Arch Allergy Immunol. 2011;155(3):257-62.

135. Kim MS, Cho YJ. Flow cytometry-assisted basophil activation test as a safe diagnostic tool for aspirin/NSAID hypersenstivity. Allergy Asthma Immunol Res. 2012;4(3):137-42.

136. Abuaf N, Rostane H, Barbara J, Toly-Ndour C, Gaouar H, Mathelier-Fusade P, et al. Comparison of CD63 upregulation induced by NSAIDs on basophils and monocytes in patients with NSAID hypersensitivity. J Allergy. 2012;2012:580873.

137. Ariza A, Fernandez TD, Dona I, Aranda A, Blanca-Lopez N, Melendez L, et al. Basophil activation after nonsteroidal antiinflammatory drugs stimulation in patients with immediate hypersensitivity reactions to these drugs. Cytom Part A: J Int Soc Anal Cytol. 2014;85(5):400-7. 